\title{
Gender-biased Appropriation of Space?
}

\section{Subjective mapping as a tool to explore primary school students' spatial action scopes}

\author{
Christian Groß and Inga Gryl \\ University of Duisburg-Essen, Germany·christian@gross-photography.de
}

Short paper

\begin{abstract}
Several studies indicate gender differences in spatial orientation, map reading, and the way people appropriate spaces for everyday action. Thereby, the most important factor of gender differences in spatially related abilities is socialization. Gender roles and differences are already present in primary school age, and gender differences in the appropriation of space may lead to unequal chances of societal participation. Therefore, it is worth drawing a focus on gender-biased education in primary geography learning. This study examines potential gender differences in primary school with subjective cartography, respectively mapping of children's everyday spaces.
\end{abstract}

Keywords: Primary school, appropriation of space, gender, subjective cartography, mapping

\section{Introduction - Gender and Spatially Related Abilities}

Several studies identify gender differences in spatial orientation, map reading, and the way people appropriate spaces for everyday action (a.o. NEIDHARDT \& SCHMITZ 2001). For instance, many women tend to use points of interest for orientation, whereas men prefer to memorize paths; women more often use egocentric (subjective), and men allocentric (overview) orientation strategies (LAMPLMAYR \& KRYSPIN-EXNER 2011). There is an ongoing discussion about the reasons for these distinctions, where arguments range from biological determination (sex), to socialization-focused (gender) explanations (QUAISER-POHL \& LEHMANN 2002). Nevertheless, poststructuralist feminist theories reveal the dichotomous system of sex specific abilities as socially constructed itself (BUTLER 1990).

Concerning spatial abilities, ambiguous findings produced by applicable studies prove this statement: In studies on perceptual psychology, mental rotation - the ability to represent the rotation of two- or three-dimensional objects mentally - was long seen as a field, where men have an advantage. However, recent studies indicate that gender differences are neither test-independent, nor appear among all age groups (QUAISER-POHL \& LEHMANN 2002; NEUBuRGER et al. 2011). HeIL et al. (2012) indeed demonstrate that the performance of mental rotation is influenced by the stereotype thread (cf. STEELE \& ARONSON 1995), meaning that women tend to perform worse when they are expected to do so. Therefore, even differences in mental rotation do not seem to be a biological fact. 
Concerning the appropriation of space - meaning the ability to attach meaning to spaces, to communicate meaning, and to act in spaces in a self-regulated manner (DAUM 2006) - the relevance of non-biologistic, socialization-focused approaches is even less disputable.

We are aware that many cultures live a highly dichotomous system on the basis of sex, reifying culturally constructed structures (NISSEN 1998). Omnipresent from birth, and throughout primary school, this dichotomous societal system of gender differences is influential in many attribution processes (Bos et al. 2003). Concerning education, it must be emphasized that different (learnt) abilities in the appropriation of spaces allocate chances of formation and participation in spatial decision making unequally and unfairly. Therefore, it is essential to draw a focus on spatial competences in primary geography learning.

\section{Subjective Mapping as Indicator for Potential Gender Differences}

This study aims to identify whether there are gender differences among primary school students, concerning basic cartographic competences (with an emphasis on productive competences), basic orientation skills, and - first and foremost - the appropriation of everyday spaces. The chosen method of data collection is "subjective cartography" (DAUM 2010), roughly circumscribed with "mapping" as a subjective tool to represent spaces.

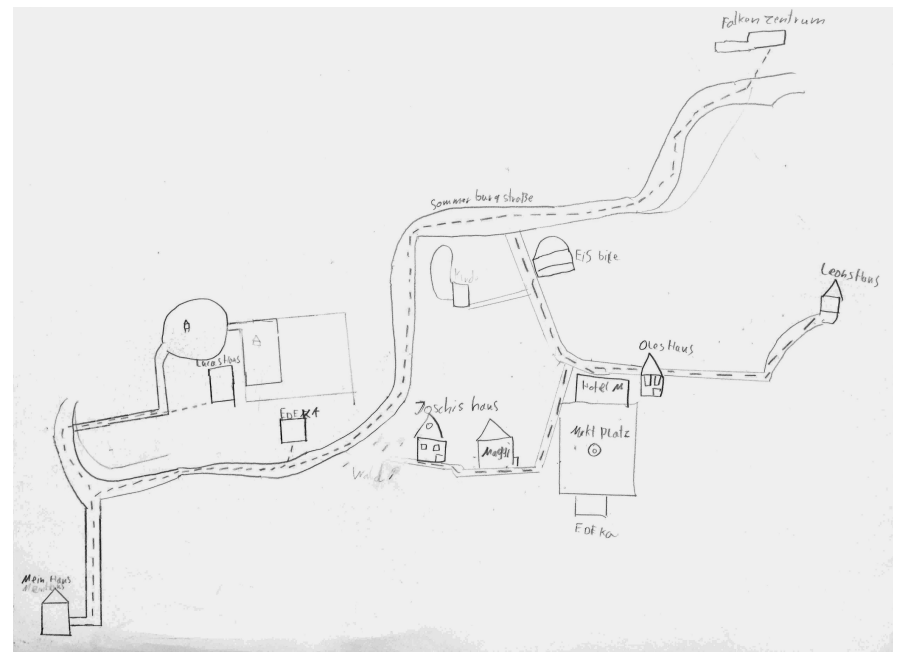

Fig. 1:

Prototype of a subjective map from the sample

The students $\left(\mathrm{N}_{\text {female }}=23, \mathrm{~N}_{\text {male }}=20\right.$, grade 3 and 4) are asked to draw the favorite places of their everyday surroundings and how they get there in a free, highly subjective manner, with a few references to geovisualization. Afterwards, their drawings and the elements in these are categorized with a coding system. This system emerges from the drawings themselves, following the grounded theory approach, and additionally takes into account theoretical heuristics (KELLE \& KLUGE 1999). The resulting categories provide insight into classic orientation skills known from mental map research (DOWNS \& STEA 1977), as well as into processes of the subjective attachment of meaning to material spaces, everyday spatial 
constructions, and power relations in space (e.g. LEFEBVRE 1993). The finalized category system allows for grouping of data, defining of patterns of orientation skills and everyday action, and identifying potential gender differences. We examine, whether these findings mirror differences known from literature (e.g. LAMPLMAYR \& KRYSPIN-EXNER 2011). Another focus is the potential deconstruction of gender-stereotypes in free-time activityrelated landmarks, and the question whether the dimensions of the children's spaces of action are gender-related.

The results indicate very few correlations between gender and the differences in the students' subjective cartographies. There are little elements that are limited to one gender's maps at all. Nevertheless, concerning the usage of functional elements and cartographic abilities, the maps vary highly, both among boys and girls. Based on this data, we can construct a common prototype (fig. 1) representing a model for most of the students, instead of gender-differentiated schemes. Thus, most students draw elements of their direct residential environment and subjective paths with few references to the existent network of roads. Mostly, we can identify a mixture of ground plans and vertical projections concerning buildings. Socially functional places such as the houses of friends and relatives are a very common element.

The only differences we could extract from the data are functional places that seem to be reserved to female students only, such as riding academy, ballet school, and music school. Following NISSEN (1998), and STRZODA \& ZINNECKER (1998), these places are associated with stereotype models of being female, as they indicate stereotypically female free time activities. Apart from that, girls also marked places as relevant to them, which are - according to literature - stereotypically attributed to boys, such as soccer fields. Altogether, regarding free time activity related places, girls seem to display a broader range, serving and ignoring stereotype gender models at the same time, while boys tendentially stick to them. Another minor difference is the usage of simple georeferences in terms of address data (street names and house numbers). While the usage of addresses in subjective cartography is higher among fourth graders, boys are always disadvantaged within this sample: While $27 \%$ of female third graders, and $92 \%$ of female fourth graders use address indices on the elements of their drawings, $0 \%$ of the male third graders and $62 \%$ of the male fourth graders do so. An explanation of this finding would remain speculative up to this point.

\section{Conclusion - Gender, Space, and Pedagogical Praxis}

The findings indicate that within this small sample of the age group, gender differences are low. Nevertheless, there are very few hints for an expectant fulfilment of societal constructions concerning free time interests and spatial activities. Further studies combining subjective cartography with interviews might deepen these insights. Up to now, we can argue for a pedagogical praxis being aware of the probably significant role of the primary years for constructing gender differences. We know, that role-taking concerning stereotype gender roles rises with age (STEINS 2008). Therefore, we need a responsible pedagogy that aims at the equality of opportunities and reduces unfair effects of an implicitly dichotomous gender-oriented education. This pedagogy must, in coherence with post-structural gender theories (BUTLER 1990) target a less dichotomous but fluid definition of gender than still present in pedagogical environments (Bos et al. 2003). Such a pedagogical approach might also be a step to an equality of chances to appropriate spaces and shape society. 


\section{References}

Bos, W., Lankes, E.-M., Prenzel, M., Schwippert, K., Walther, G. \& Valtin, R. (Eds.) (2003), Erste Ergebnisse aus IGLU. Schülerleistungen am Ende der vierten Jahrgangsstufe im internationalen Vergleich. Waxmann, Münster.

Butler, J. (1990), Gender Trouble. Feminism and the Subversion of Identity. Routledge, New York.

DAUM, E. (2006), Raumaneignung. Grundkonzeption und unterrichtspraktische Relevanz. GW-Unterricht 2006, 103, 7-16.

DAUM, E. (2010), Heimatmachen durch Subjektives Kartographieren. Sachunterricht, 2/2010, 17-21.

DOWns, R. M. \& STEA, D. (1977), Maps in minds. Reflections on cognitive mapping. Harper \& Row, New York.

HeIl, M., Jansen, P., QuAiser-Pohl, C. \& Neuburger, S. (2012), Genderspecific effects of artifically induced gender beliefs in mental rotation. Learning and Individual Differences, 22, 350-353.

Hirnstein, M. \& Hausmann, M. (2010), Kognitive Geschlechtsunterschiede. In: Steins, G. (Ed.), Handbuch Psychologie und Geschlechterforschung. VS, Wiesbaden, 69-85.

Kelle, U. \& Kluge, S. (1999), Vom Einzelfall zum Typus. Leske + Budrich, Opladen.

LAMPLMAYR, E. \& KRYSPIN-EXNER, I. (2011), Gender-Aspekte in der Neuropsychologie. In: Lehrner, J., Pusswald, G., Fertl, E., Strubreither, W. \& Kryspin-Exner, I. (Eds), Klinische Neuropsychologie. Grundlagen, Diagnostik, Rehabilitation. Springer, Wien.

LefebVRE, H. (1993), The Production of Space. Blackwell, Oxford.

NeIDHARDT, E. \& SchMiTZ, S. (2001), Entwicklung von Strategien und Kompetenzen in der räumlichen Orientierung und in der Raumkognition. Psychologie in Erziehung und Unterricht 2001, 48, 262-279.

Neuburger, S., Jansen, P., Heil, M. \& QuAiser-Pohl, C. (2011), Gender differences in pre-adolescents' mental-rotation performance: Do they depend on grade and stimulus type? Personality and Individual Differences 2011, 50, 1238-1242.

NiSSEN, U. (1998), Kindheit, Geschlecht und Raum. Sozialisationstheoretische Zusammenhänge geschlechtspezifischer Raumaneignung. Juventa, Weinheim.

QuAiser-Pohl, C. \& LeHMANN, W. (2002), Girls‘ spatial abilities. Charting the contributions of experience and attitudes in different academic groups. British Journal of Educational Psychology 2002, 72, 245-260.

SteEle, C. M. \& ARONSON, J. (1995), Stereotype threat and the intellectual performance of African Americans. Journal of Personality and Soc. Psychology 1995, 69, 797-811.

STEINS, G. (2008), Grundlagen der Entwicklung geschlechtsspezifischer Differenzen. In: STEINS, G. (Hrsg.): Geschlechterstereotype in der Schule - Realität oder Mythos? Anregungen aus und für die schulische Praxis. Pabst Science Publ., Lengerich, 12-21.

STRZODA, C. \& ZINNECKER, J. (1998): Interessen, Hobbies und deren institutioneller Kontext. In: Kindheit in Deutschland. Aktueller Survey über Kinder und ihre Eltern. Juventa, Weinheim. 